\title{
PENGEMBANGAN DESAIN SEPEDA KAYUH REKREASI TIGA PENUMPANG
}

\author{
Muhammad Arifudin Lukmana \\ Program Studi Teknik Mesin, UPN “Veteran” Jakarta, Jakarta Selatan, Indonesia \\ Email: arifudin17@yahoo.co.id
}

\begin{abstract}
Cycles are not only used as transportation, but also sport and recreational utility. Cycle is a cheap and eco-friendly transportation. But it has several disadvantages in comfort and travel distance. Because of its limitation, people these days use cycle for sport and recreational tool. In eco-friendly environments, people are forced to use pollution-free vehicle. Several campuses, parks, factories and offices use cycle to support eco-friendly campaign. Tandem bike is cycle for leisure and driven by two or more person. Family activity, communication, light sport and transportation can be done by driving a tandem bike. This cycling activity is suitable for people who live in the busy city. This paper is studying process of designing a recreational tandem bike for three people. The study compares existing three or four-driver tandem bike with two new concepts. After selection using scoring based on criteria, selected concept is designed in detail. Evaluations of design use 2 dimension Cremona method and finite element method.
\end{abstract}

Keywords: Cycle, Design, Tandem.

\section{PENDAHULUAN \\ Latar Belakang}

Sepeda bukan hanya sebagai sarana transportasi, namun juga dapat digunakan sebagai sarana olahraga dan rekreasi. Sebagai sarana transportasi, sepeda adalah transportasi yang murah dan ramah lingkungan. Namun, sepeda memiliki beberapa kelemahan untuk kenyamanan dan jarak tempuh. Karena keterbatannya, saat ini masyarakat lebih sering menggunakan sepeda sebagai sarana olahraga dan rekreasi.

Gaya hidup warga perkotaan yang sibuk membuat waktu berolahraga dan berkumpul menjadi sesuatu yang jarang. Sepeda tandem dapat menjadi jawaban dari permasalahan tersebut. Sepeda tandem adalah sepeda yang didesain untuk dikendarai lebih dari satu orang. Sehingga beban yang seharusnya dipikul satu orang saat bersepeda dapat dibagi dengan rekannya. Selain itu itu dengan menggunakan sepeda tandem maka komunikasi antar pengendara akan menjadi semakin erat. Dengan demikian waktu untuk berolahraga dan berkumpul bersama keluarga atau teman dapat digabung menjadi satu sehingga dapat mengakomodasi gaya hidup warga kota yang sibuk.

\section{Perumusan Masalah}

Rumusan masalah pada laporan ini adalah bagaimana merancang sebuah sepeda dengan kapasitas penumpang 3 orang dan mampu mengangkut barang dengan kapasitas maksimum $50 \mathrm{Kg}$.

\section{Batasan Masalah}

Batasan masalah yang ditentukan dalam laporan ini adalah:

1. Sepeda dirancang untuk penumpang tiga orang

2. Berat badan penumpang maksimal $70 \mathrm{~kg}$.

3. Berat barang bawaan di belakang maksimal $50 \mathrm{~kg}$.

4. Permukaan jalan dianggap rata sehingga tidak perlu perancangan suspensi khusus.

\section{Tujuan Pengembangan Produk}

Produk sepeda rekreasi ini ditujukan sebagai sarana untuk mendukung program eco-campus yang dijalankan oleh beberapa kampus, sekolah, taman kota, pabrik dan perkantoran. Selain itu juga untuk memenuhi kebutuhan masyarakat perkotaan akan olahraga dan rekreasi.

\section{TINJAUAN PUSTAKA}

\section{Desain sepeda kayuh depan (Recumbent bi-cycle)}

Recumbent bicycle adalah sepeda kayuh dengan posisi pengendara bersandar kebelakan dengan sudut tertentu. Sebagian besar pengendara recumbent memilih jenis ini karena alasan ergonomis. Berat pengendara didistribusikan merata ke seluruh luasan tempat duduk melalui punggung dan pantat. Dibandingkan sepeda tradisional, berat badan disalurkan seluruhnya pada sebagian kecil pantat, kaki dan tangan. 


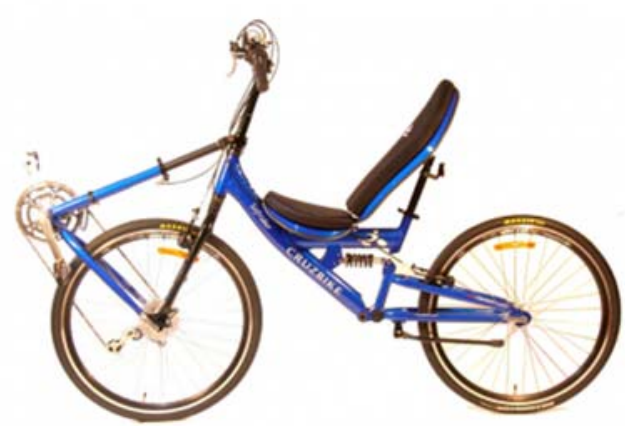

Gambar 1 Sepeda Recumbent tipe sofrider cruzbike (sumber: Wikipedia)

Sebagian besar sepeda recumbent memiliki keuntungan aerodinamik, posisi badan menyudut kebelakang dan kaki kedepan membuat profil pengendara mengecil. Sebuah sepeda jenis ini memegang rekor dunia kecepatan untuk sepeda kayuh. Sepeda recumbent memiliki varian bentuk seperti: ukuran roda besar, kecil atau campuran; jarak antar poros panjang atau pendek; overseat, underseat, tanpa setir tangan; rear wheel drive atau front wheel drive.

\section{PENGEMBANGAN DAN PEMILIHAN KONSEP}

Dalam pengembangan produk dibutuhkan daftar kebutuhan. Tabel 1 di bawah ini adalah daftar kebutuhan untuk pengembangan sepeda rekreasi

Tabel 1 Daftar Kebutuhan Pengembangan Produk

\begin{tabular}{|l|l|l|}
\hline $\begin{array}{c}\text { Syarat/ } \\
\text { Harapan }\end{array}$ & \multicolumn{1}{|c|}{ Uraian Kebutuhan } & \multicolumn{1}{|c|}{$\begin{array}{c}\text { Penanggung } \\
\text { Jawab }\end{array}$} \\
\hline Syarat & Berfungsi untuk rekreasi & Team Desain \\
\hline Syarat & Berfungsi untuk olahraga & Team Desain \\
\hline Syarat & Bisa untuk bawa barang & Team Desain \\
\hline Syarat & Kuat & Team Desain \\
\hline Syarat & Dapat dimanufaktur & Team Fabrikasi \\
\hline Syarat & Mudah dirakit & $\begin{array}{l}\text { Team Desain dan } \\
\text { Team Fabrikasi }\end{array}$ \\
\hline Syarat & Atap bisa dibongkar & $\begin{array}{l}\text { Team Desain dan } \\
\text { Team Fabrikasi }\end{array}$ \\
\hline Syarat & Kapasitas 3 orang & Team Desain \\
\hline Syarat & Dibantu dengan motor listrik & Team Desain \\
\hline Harapan & Ergonomis & Team Desain \\
\hline Harapan & Harga terjangkau & Team Fabrikasi \\
\hline Harapan & Tidak lebih dari $100 \mathrm{~kg}$ & Team Fabrikasi \\
\hline
\end{tabular}

\section{Konsep Referensi (Existing Product)}

Sebagai referensi dalam pengembangan produk ini adalah sepeda dengan penumpang 4- 6 orang yang sudah dijual dipasaran. Rangka dibuat dari baja profil yang dilas dan dicat dengan warna pesanan. Kayuhan berjumlah empat, memiliki atap, memiliki bak keranjang di depan, transmisi menggunakan rantai dan dapat diatur rasionya. Untuk keamanan, produk ini dilengkapi rem, bel, kaca spion dan lampu LED untuk malam hari. Steering menggunakan setir mirip mobil roda empat.

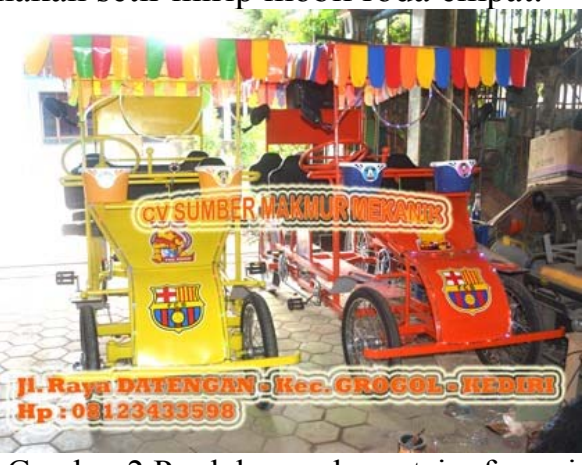

Gambar 2 Produk sepeda santai referensi

\section{Konsep Alternatif}

Terdapat dua rancangan konsep alternatif, yakni konsep A dan konsep B. Perancangan kedua konsep berdasarkan Tabel 1 yang telah dijelaskan sebelumnya. Perbedaan besar pada setiap konsep dijelaskan pada tabel 2 berikut.

Tabel 2 Perbandingan Konsep A dan B

\begin{tabular}{|l|l|}
\hline \multicolumn{1}{|c|}{ KONSEP A } & \multicolumn{1}{|c|}{ KONSEP B } \\
\hline - Menggerakkan 1 roda & $\bullet$ Menggerakkan ketiganya \\
saja & $\bullet$ Kayuhan tidak sinkron \\
- Kayuhan sinkron & $\bullet$ Membutuhkan 2 motor \\
- Membutuhkan 1 motor & listrik \\
listrik & $\bullet$ Steering menggunakan \\
- Steering menggunakan & stang \\
roda setir & Kapasitas volume barang \\
Kapasitas volume barang & lebih besar \\
\hline
\end{tabular}

Kedua konsep digambarkan dengan sketsa dengan memenuhi segala persyaratan dan alternatif konsep dari Tabel 2. Didapatkan sketsa konsep A dan B pada gambar 3 dan gambar 4 berikut.

\section{Konsep A}
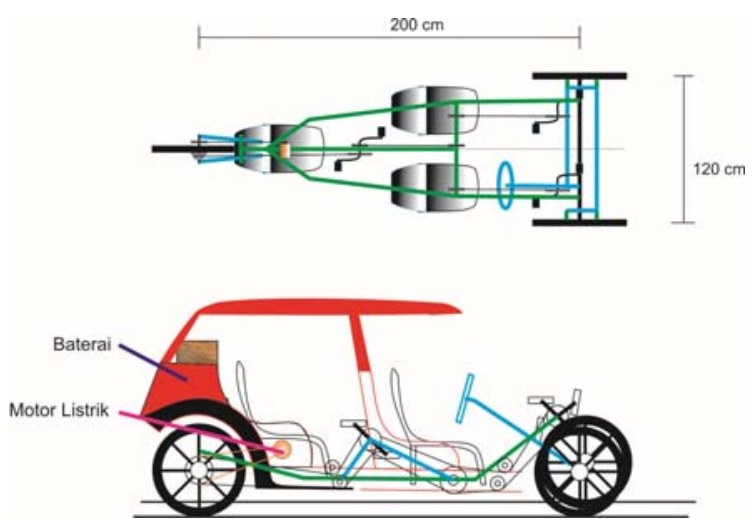

Gambar 3 Konsep A 
Cara kerja konsep A ini adalah menggunakan satu roda penggerak dibagian belakang, pengemudi berada di depan sebelah kanan. Dalam rancangan ini, bentuk sepeda cenderung lebih rendah dan letak barang berada dibelakang. Dilengkapi dengan atap yang dapat dibongkar-pasang. Motor listrik dan baterai terletak di kursi belakang. Menggunakan 1 motor saja sebagai penggerak satu roda belakang

\section{Konsep B}

Pada konsep B, perbedaan mencolok adalah stang pengemudi, roda di depan berjumlah 1 dan di belakang 2 roda.
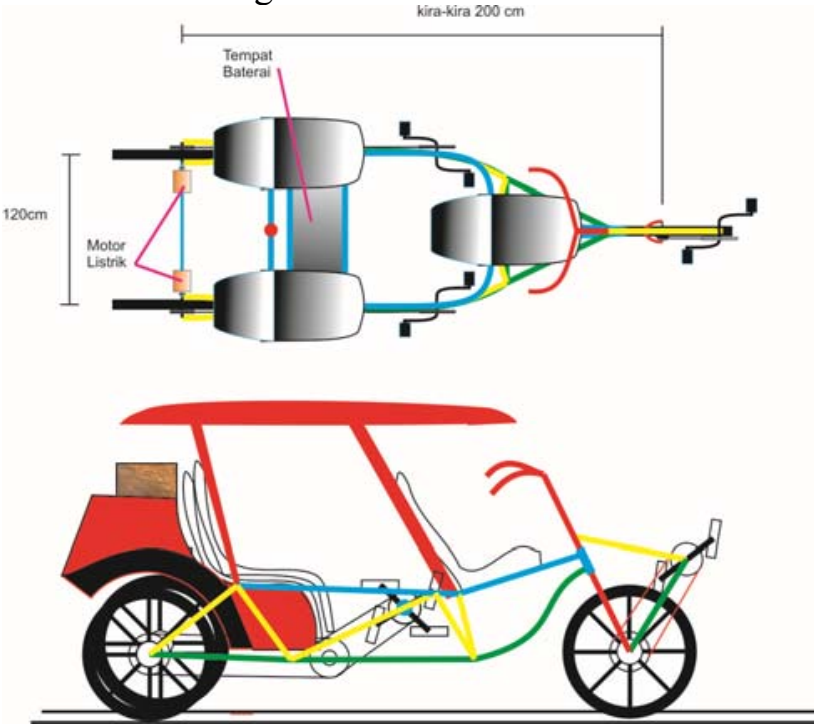

Gambar 4 Konsep B
Rangka kendaraan cenderung tinggi dengan rangka terbuat dari aluminium tabung seperti sepeda kayuh konvensional.

Sepeda ini mengadopsi front wheel drive sekaligus rear wheel drive. Pengemudi di depan mengadopsi bentuk sepeda recumbent ditunjukkan dengan sudut duduk dan posisi kayuhan. Dua roda belakang berfungsi sebagai penggerak menggunakan sistem one-way bearing. Bagasi yang terletak di bagian belakang lebih luas karena ditahan oleh dua roda. Motor listrik direncanakan berada dibelakang pada masing-masing roda. Diharapkan dengan adanya motor ini steering menjadi lebih baik.

Merujuk pada tabel 3 dapat diambil keputusan bahwa Konsep terpilih adalah Konsep B dengan nilai absolut 3,73 dan nilai relatif $36,39 \%$. Untuk selanjutnya pengembangan alat berpegang pada konsep $\mathrm{B}$. Dengan menggunakan software $C A D 3$ Dimensi didapatkan detail konsep B seperti yang ditampilkan pada gambar 4 dan gambar 5 .

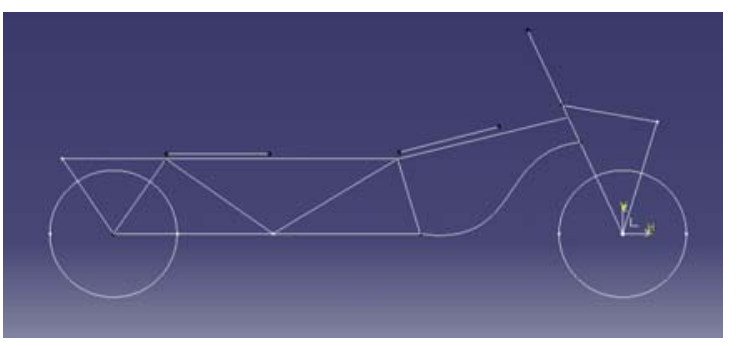

Gambar 4 Sketsa desain sepeda dalam 2 dimensi

\section{Pemilihan Konsep (Screening and/or Scoring)}

Tabel 3 Seleksi Konsep Sepeda Rekreasi

\begin{tabular}{|c|c|c|c|c|c|c|c|c|}
\hline \multirow{3}{*}{ No. } & \multirow{3}{*}{ Kriteria Seleksi } & \multirow{3}{*}{$\begin{array}{c}\text { Bobot } \\
(\%)\end{array}$} & \multicolumn{6}{|c|}{ Konsep } \\
\hline & & & \multicolumn{2}{|c|}{ Konsep A } & \multicolumn{2}{|c|}{ Konsep B } & \multicolumn{2}{|c|}{ Konsep Referensi } \\
\hline & & & Rate & $\begin{array}{l}\text { Skor } \\
\text { bobot }\end{array}$ & Rate & $\begin{array}{l}\text { Skor } \\
\text { bobot }\end{array}$ & Rate & $\begin{array}{l}\text { Skor } \\
\text { bobot }\end{array}$ \\
\hline 1 & Berfungsi untuk rekreasi & 10 & 3 & 0,3 & 3 & 0,3 & 3 & 0,3 \\
\hline 2 & Berfungsi untuk olahraga & 8 & 4 & 0,32 & 4 & 0,32 & 3 & 0,24 \\
\hline 3 & Bisa untuk bawa barang & 9 & 4 & 0,36 & 5 & 0,45 & 3 & 0,27 \\
\hline 4 & Kuat & 15 & 3 & 0,45 & 3 & 0,45 & 3 & 0,45 \\
\hline 5 & Dapat dimanufaktur & 10 & 3 & 0,3 & 3 & 0,3 & 3 & 0,3 \\
\hline 6 & Mudah dirakit & 10 & 4 & 0,4 & 4 & 0,4 & 3 & 0,3 \\
\hline 7 & Atap bisa dibongkar & 7 & 5 & 0,35 & 5 & 0,35 & 3 & 0,21 \\
\hline 8 & Kapasitas Penumpang & 8 & 2 & 0,16 & 2 & 0,16 & 3 & 0,24 \\
\hline 9 & $\begin{array}{l}\text { Dibantu dengan motor } \\
\text { listrik }\end{array}$ & 12 & 4 & 0,48 & 5 & 0,6 & 3 & 0,36 \\
\hline 10 & Ergonomis & 5 & 5 & 0,25 & 5 & 0,25 & 3 & 0,15 \\
\hline 11 & Harga terjangkau & 3 & 2 & 0,06 & 2 & 0,06 & 3 & 0,09 \\
\hline 12 & Tidak lebih dari $100 \mathrm{~kg}$ & 3 & 3 & 0,09 & 3 & 0,09 & 3 & 0,09 \\
\hline & Nilai Absolut & 100 & & 3,52 & & 3,73 & & 3 \\
\hline & Nilai Relatif & & & $34,34 \%$ & & $36,39 \%$ & & $29,27 \%$ \\
\hline
\end{tabular}




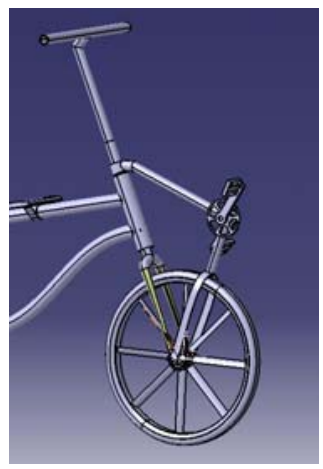

Gambar 5 Mekanisme kayuh untuk roda depan

\section{PERANCANGAN KOMPONEN}

\section{Analisa Tegangan Secara Manual}

Analisa tegangan manual menggunakan metode grafis (cremona). Struktur sepeda dianggap sebagai batang truss dengan asumsi gambar 2 dimensi. Tujuan analisa ini adalah mendapatkan ketebalan minimal material tabung (tube) kerangka sepeda.

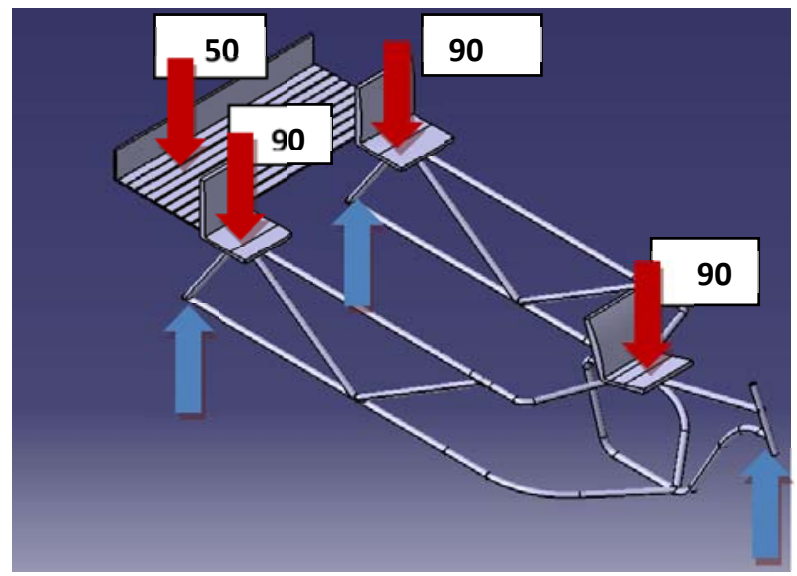

Gambar 6 Peletakan beban aktual

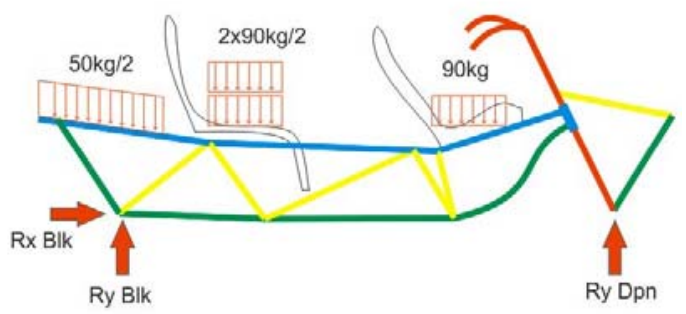

Gambar 7 Penyederhanaan freebody diagram 2 Dimensi

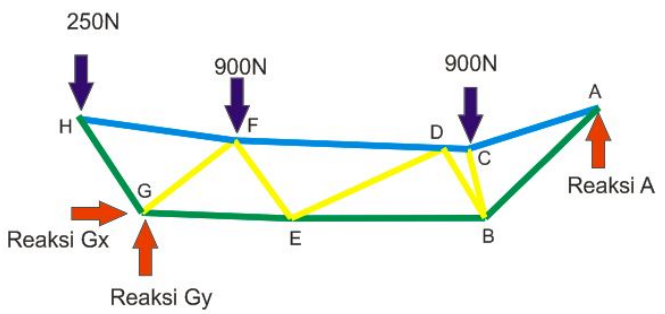

Gambar 8 Free body diagram dengan beban terpusat

Proses penyederhanaan ditampilkan oleh gambar 7 dengan menentukan tumpuan engsel dan roll. Gambar 8 adalah penyederhanaan selanjutnya dengan meletakkan beban pada sambungan antar batang.

Tabel 4 Detail Ukuran Tiap Batang

\begin{tabular}{|c|c|c|c|}
\hline Batang & $\begin{array}{c}\text { Panjang } \\
(\mathrm{mm})\end{array}$ & Batang & $\begin{array}{c}\text { Panjang } \\
(\mathrm{mm})\end{array}$ \\
\hline AB & 740 & DF & 910 \\
\hline AC & 625 & EF & 510 \\
\hline BC & 315 & EG & 627 \\
\hline BD & 300 & FG & 360 \\
\hline BE & 577 & FH & 375 \\
\hline CD & 60 & GH & 360 \\
\hline DE & 570 & & \\
\hline
\end{tabular}

$\Sigma \mathrm{Fx}=0$

$\operatorname{Rgx}=0$

$\Sigma \mathrm{Fy}=0$

$-250-900-900+\mathrm{RA}+\mathrm{RGy}=0$

$\mathrm{RA}+\mathrm{RGy}=2050 \mathrm{~N}$

$\mathrm{Rgy}=2050-\mathrm{RA}$

$\Sigma \mathrm{MG}=0(\mathrm{CCW})$

Gy.0 + 250.0,166 - 900.0,213 - 900.1,177+

RA. $2=0$

$83-383,4-1059,3+2 \mathrm{RA}=0$

$\mathrm{RA}=1209,5 / 2$

$\mathrm{RA}=604,25 \mathrm{~N}$

Maka, Rgy=2050 - 604,25;

$\mathrm{Rgy}=1445,25$

\section{Penyelesaian dengan Metode Grafis (Cremona)}

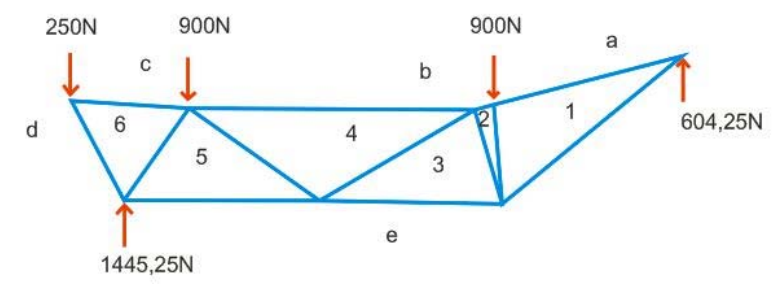

Gambar 9 Freebody diagram 2 Dimensi lengkap dengan gaya eksternal 


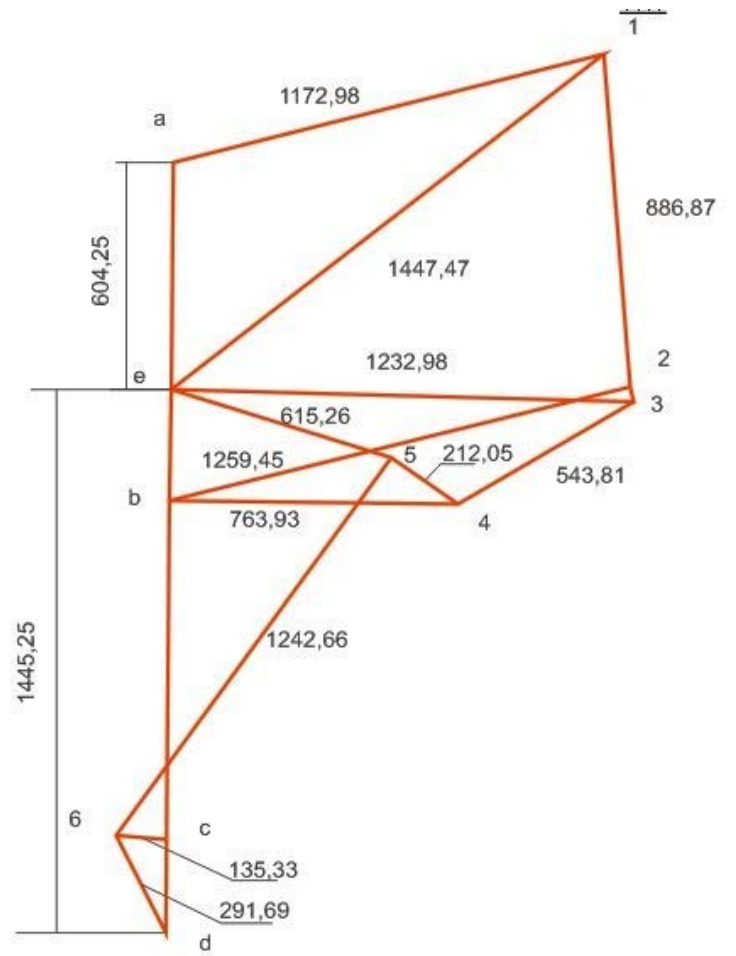

Gambar 10 Grafis vektor gaya pada rangka sepeda

Dari diagram Gambar 10, dapat

diketahui

Bahwa ranking tegangan terbesar adalah:

e-1 : 1447,47 N (Tarik)

b-2 : 1259,45 N (Tekan)

$5-6: 1242,66 \mathrm{~N}$ (Tekan)

e-3 : 1232,98 N (Tarik)

a-1 : 1172,98 N (Tekan)

$1-2: 886,87 \mathrm{~N}$ (Tekan)

b-4 : 763,98 N (Tekan)

Tegangan terbesar terdapat pada batang 1 .

Pada gambar 11 batang 1 ditunjukkan oleh lingkaran. Pada batang tersebut diharuskan kuat dengan mengatur bahan dan dimensinya. Apabila bagian kritis tersebut sudah kuat, maka bagian lainnya tidak perlu diperhatikan karena mengalami tegangan yang lebih kecil dari batang 1 .

\section{Faktor Keamanan}

Diketahui tegangan maksimal sebesar 1447,47 N (tarik)

Faktor Keamanan $=$ Kekuatan Material $/$ beban Apabila menggunakan faktor keamanan $=2$, maka 2,= Kekuatan Material / 1447,47 N

Kekuatan Material minimal adalah $1447,47 \mathrm{~N} \mathrm{x}$ $2=\mathbf{2 8 9 4 , 9 4} \mathrm{N}$

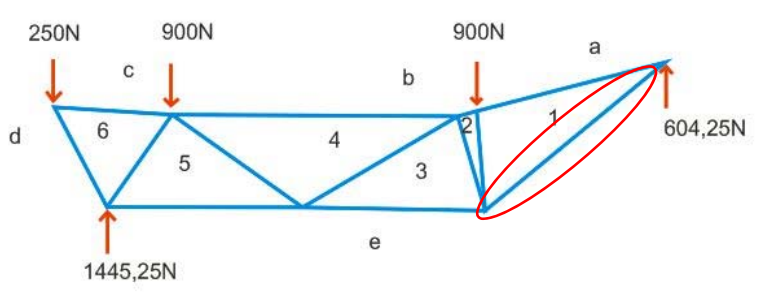

Gambar 11 Bagian kritis ada pada batang 1, ditandai dengan lingkaran.

\section{Geometri Tabung}

Struktur rangka sepeda disusun dengan menggunakan bahan alumunium profil silinder hollow seperti gambar 12 di bawah ini.

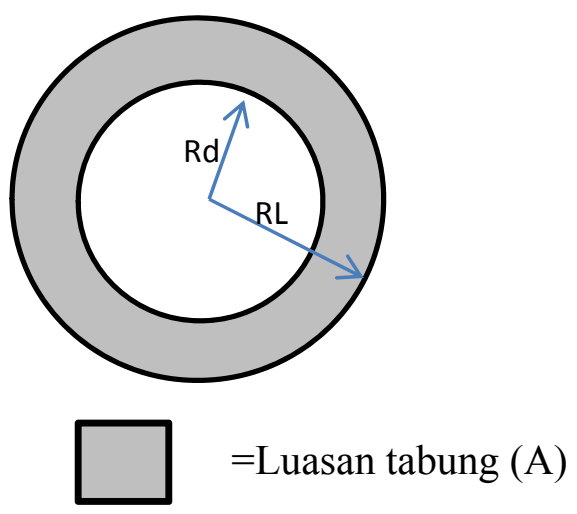

Gambar 12 Profil Aluminium penyusun rangka sepeda

$\operatorname{Luasan}(\mathrm{A})=\pi(\mathrm{R} l-\mathrm{Rd})^{2}$

$\sigma=\mathrm{F} / \mathrm{A}$

$\sigma=2894,94 / \pi(\mathrm{RL}-\mathrm{Rd})^{2}$

Jika menggunakan material Aluminium 6061-O

Dengan Yield Strength $55 \mathrm{MPa}$, maka

$55.000 .000=921,96 /(\mathrm{RL}-\mathrm{Rd})^{2}$

$(\mathrm{RL}-\mathrm{Rd})^{2}=921,96 / 55.000 .000$

$(\mathrm{RL}-\mathrm{Rd})^{2}=1,676 \mathrm{E}-05 \mathrm{~m}^{2}$

$\mathrm{RL}-\mathrm{Rd}=0,004094$ meter

Rl-Rd = 4,094 mm (tebal minimal)

\section{Analisa Tegangan dengan Metode Elemen Hingga untuk kasus Statik}

Berikut adalah analisa struktur dengan menggunakan metode elemen hingga. Struktur yang dianalisaadalah rangka utama sepeda. Komponen ini merupakan komponen utama produk. Komponen ini menerima seluruh beban dari penumpang dan barang kemudian menyalurkan ke tanah melalui roda-roda. Letak dan besar input beban sesuai dengan gambar 13. Konstrain berada pada daerah garpu sepeda dan bearing pada bagian belakang. 


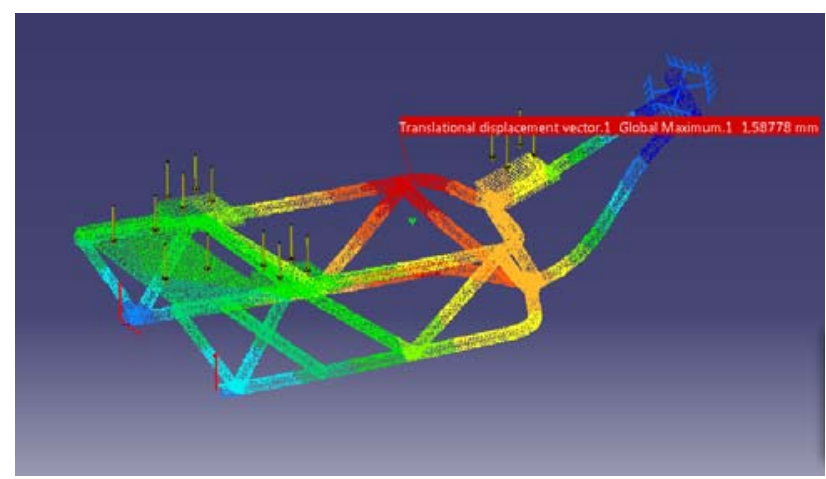

Gambar 13 Vektor displacement pada rangka sepeda

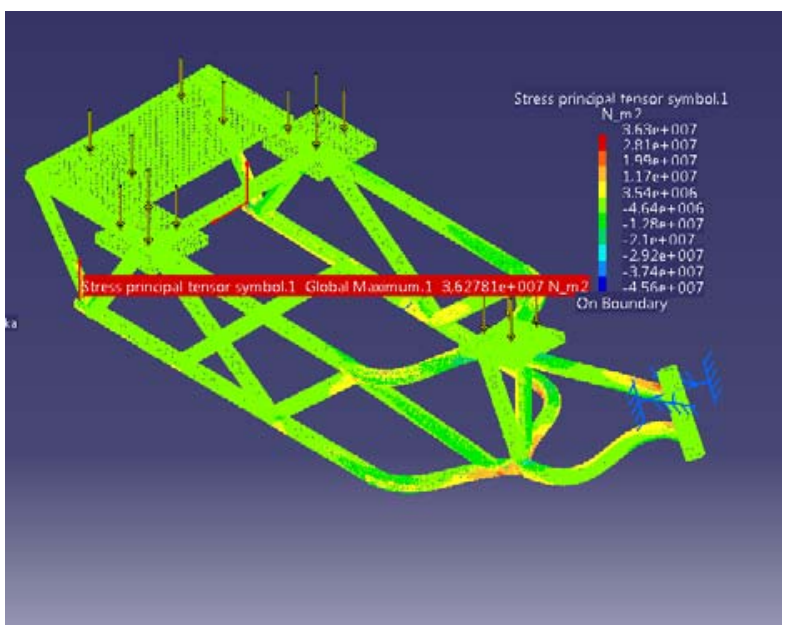

Gambar 14 Tegangan Principal Tensor

Hasil simulasi menunjukkan bahwa tegangan terbesar berada pada ujung belakang sepeda. Besar tegangan adalah 36,278 $\mathrm{MPa}$, masih lebih kecil daripada kekuatan material Al T6061sebesar 110 MPa. Maka struktur rangka sepeda ini dikategorikan aman dengan faktor keamanan = $110 / 36,278=\mathbf{3 , 0 3 2 1}$

\section{Desain Akhir Sepeda}

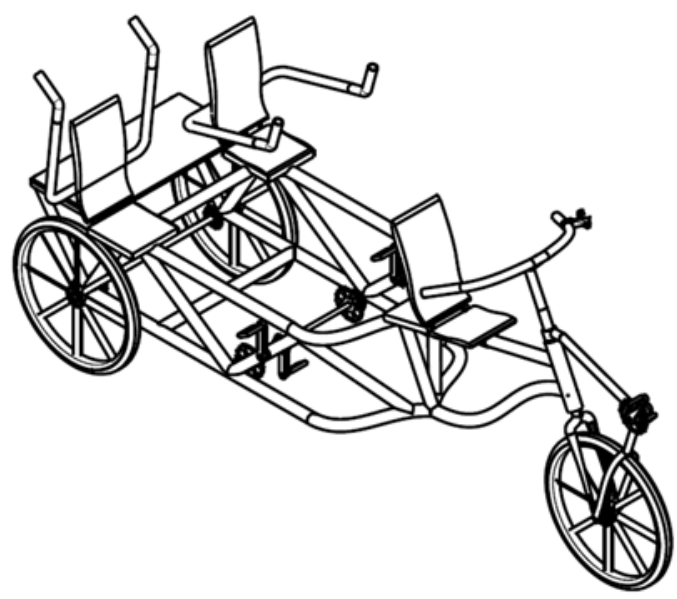

Gambar 14 Desain akhir tampilan isometrik

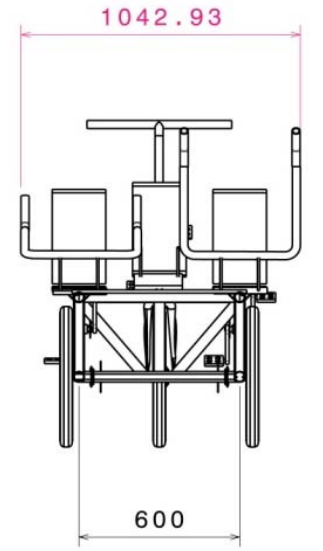

Gambar 15 Tampak belakang

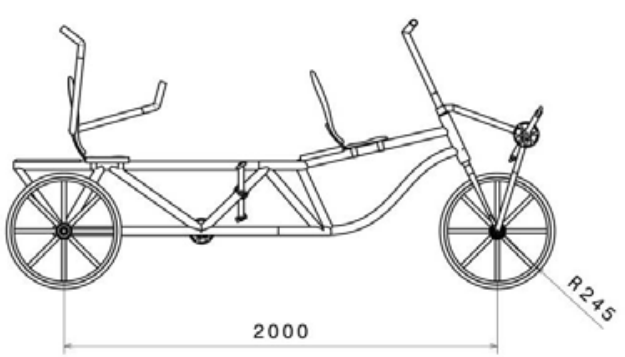

Gambar 16 Tampak samping

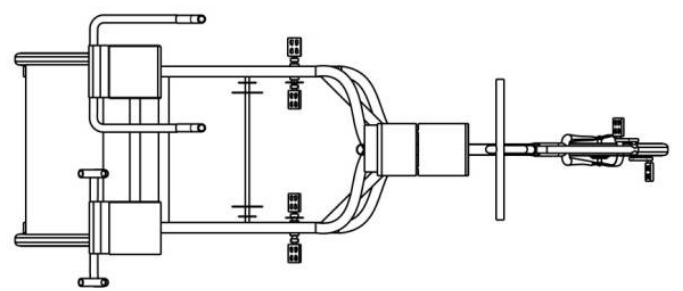

Gambar 17 Tampak atas

\section{SIMPULAN \\ Kesimpulan}

Dengan merujuk pada bahasan bab-bab sebelumnya, dapat disimpulkan sebagai berikut:

1. Telah dirancang sepeda dengan penumpang 3 orang dan barang $50 \mathrm{~kg}$.

2. Rangka Sepeda menggunakan material Aluminium T6061 berbentuk tabung dengan diameter dalam $36 \mathrm{~mm}$ dan diameter luar 40 $\mathrm{mm}$.

3. Posisi pengendara mengacu pada model recumbent bicycle. 
4. Faktor keamanan yang dimiliki sepeda santai ini adalah 3,0321 .

\section{Saran}

Untuk lebih baiknya perlu adanya perancangan suspensi agar kenyamanan penumpang meningkat. Selain itu perlu juga penambahan atap yang bisa dibongkar dan dilipat agar penumpang tidak kepanasan maupun terkena hujan.

\section{DAFTAR PUSTAKA}

R.S. Khurmi, J.K. Gupta (2005), "A Textbook of Machine Design”, Eurasia Publishing House (PVT.) LTD., New Delhi.

Beer, Ferdinand P. Dan E. Russel Johnston, Jr (2009), "Vector Mechanics for Engineers - Static and Dynamic Ninth Edition", Mc Graw Hill, United States Jasperse, Bert (2010) "Quattrocycle User Manual" Bremkant Middelbeers, Netherlands

Batan, I Made Londen (2012), "Desain Produk, Edisi Pertama”, Inti Karya Guna, Surabaya 